\title{
Penyebaran Batuan Situs Purbakala Candi Palgading di Dusun Palgading, Desa Sinduharjo, Kecamatan Ngaglik, Kabupaten Sleman, Daerah Istimewa Yogyakarta dengan Menggunakan Metode Resistivitas Dipole Dipole
}

\author{
Usmardin $^{1}$ dan Sismanto ${ }^{2}$ \\ ${ }^{1}$ Jl. Bunga Nusa Indah No. 45 B Kemaraya Kendari. \\ ${ }^{2}$ Laboratorium Geofisika, Jurusan Fisika, Fakultas Matematika dan Ilmu Pengetahuan Alam \\ Universitas Gadjah Mada, Yogyakarta.
}

\begin{abstract}
Abstrak
Telah dilakukan pemetaan dengan metode resistivitas mapping konfigurasi Dipole Dipole di sekitar Situs Candi Palgading yang terletak di Desa Sinduharjo, Ngaglik, Sleman, D.I.Yogyakarta tanggal 1 Juli 2009 sampai 4 Juli 2009 dengan menggunakan alat Resistivitymeter. Pemetaan ini bertujuan untuk mengetahui penyebaran dan kedalaman batuan penyusun candi pada Situs Candi Palgading serta sebagai sumber informasi bagi usaha penemuan benda-benda purbakala yang terpendam dalam tanah. Pengambilan data dilakukan dengan menggunakan 8 lintasan ukur, dan mencakup luas daerah pengukuran $\pm 1000 \mathrm{~m} 2$. Lintasan 1, 2, 3, 4, 5, 6 dan 8 mengambil jarak rentang elektroda $(a=3 \mathrm{~m})$ sedangkan lintasan 7 jarak rentang elektrodanya $(a=2 \mathrm{~m})$. Keseluruhan lintasan menggunakan $n=1$ sampai dengan $n=7$. Pengolahan data menggunakan software Res2dinv dan surfer. Nilai resistivitas yang digunakan untuk menentukan batuan penyusun candi adalah nilai resistivitas batu andesit. Hasilnya menunjukkan profil nilai resistivitas batuan penyusun candi 750 Ohm-m sampai 5000 Ohm-m yang berada hingga kedalaman rata-rata 4,5 $\mathrm{m}$ sebagai batu andesit. Terdapat 7 lokasi yang diduga merupakan batu andesit penyusun Candi Palgading sedangkan salah satu lokasi yang lain merupakan batuan andesit bukan penyusun candi. Batuan candi pada ketujuh lokasi tersebut salah satunya telah tersingkap yakni di lokasi 4 sedangkan lokasi yang lain batuan candinya masih terpendam.
\end{abstract}

Kata kunci: Candi Palgading, Resistivitas

\section{Pendahuluan}

Metode geofisika banyak berperan dalam mendeteksi atau menduga kondisi bawah permukaan suatu tempat. Salah satunya dengan metode resistivitas (geolistrik). Metode resistivitas banyak digunakan dalam bidang eksplorasi sumber daya alam, mineral dan fluida serta struktur bawah permukaan. Metode ini juga banyak digunakan untuk pendeteksian benda-benda yang terkubur oleh longsoran maupun proses sedimentasi. Pendeteksian situs-situs purbakala juga dapat menggunakan metode resistivitas. Situs-situs purbakala pada umumnya ditemukan tanpa disengaja oleh warga yang sedang menggali tanah untuk membuat sumur maupun pembuatan pondasi bangunan, yang kemudian ditindaklanjuti oleh lembaga Balai Pelestarian Peninggalan Purbakala Yogyakarta. Sebab penemuan benda-benda tersebut merupakan kekayaan budaya yang harus dijaga. Dalam pelaksanaannya, untuk mengetahui lebih lanjut keadaan dan bentuk benda cagar budaya tersebut, dilakukan penggalian/ekskavasi, yang kemungkinan bisa merusak tanah disekitarnya. Untuk enghindari hal ini, maka dilakukan survei atau penyelidikan bawah permukaan supaya didapat informasi tentang keberadaan dari benda cagar budaya tersebut sebelum digali lebih jauh. 
Penelitian ini bertujuan mengetahui penyebaran dan kedalaman batuan penyusun candi pada Situs Candi Palgading serta sebagai informasi bagi usaha penyelidikan dan penemuan benda-benda purbakala yang terpendam dalam tanah.

Pengambilan data dilaksanakan pada tanggal 1 Juli sampai dengan 4 Juli 2009 yang berlokasi di obyek situs candi Dusun Palgading Desa Sinduharjo, Kecamatan Ngaglik, Kabupaten Sleman Provinsi Daerah Istemewa Yogyakarta. Secara geografis berada pada koordinat 70 7 26,065" LS dan 1100 4' 10,819” BT atau pada koordinat UTM Easting 435029 m dan Northing $9145941 \mathrm{~m}$ seperti yang disajikan pada Gambar 1 .

Gambar 2 adalah lintasan pengukuran daerah penelitian. Keberhasilan metode resistivitas untuk bidang arkeologi seperti Faridl, (1997) melakukan mapping resistivitas permukaan di situs candi Kedulan-DIY dengan menggunakan konfigurasi Wenner dan spasi elektroda $4 \mathrm{~m}$, hasilnya berupa kontur resistivitas dua dimensi. Hasil pemetaan resistivitas ini menunjukkan keberadaan batuan berupa pagar pertama candi sisi selatan di komplek candi Kedulan.

Asmanto, (2002) melakukan survey resistivitas mapping di situs candi Kadisuko-DIY dengan menggunakan konfigurasi Wenner dan spasi elektroda $1 \mathrm{~m}$, hasilnya berupa peta kontur resistivitas dua dimensi. Hasil pemetaan resistivitas ini menunjukkan adanya kenampakan batu bangunan candi pada kedalaman $1 \mathrm{~m}-2 \mathrm{~m}$. Sismanto dan Zaman (2005) melakukan pemetaan penyebaran resistivitas di sekitar lokasi Candi Morangan-DIY dengan menggunakan konfigurasi Wenner dan spasi elektroda $1 \mathrm{~m}, 2 \mathrm{~m}$ dan $3 \mathrm{~m}$. Hasilnya menunjukkan empat lokasi timbunan batu yang diduga sebagai batuan arkeologi situs Candi Morangan.

\section{Dasar Teori}

Pada metode resistivitas, arus listrik searah (DC) dialirkan pada permukaan tanah sehingga beda potensial pada dua titik dapat diukur. Variasi nilai resistivitas terhadap kedalaman akibat dialirkannya arus listrik menyebabkan variasi beda potensial yang berbeda pula sehingga informasi struktur dan material bawah permukaan dapat diberikan. Prinsip kerja metode ini adalah dengan mengukur beda potensial pada titik-titik di permukaan bumi yang dihasilkan oleh aliran arus listrik searah (DC) yang melewati bawah permukaan. Tujuan dari metode ini adalah mengetahui distribusi resistivitas bawah permukaan sehingga material-material bumi dekat permukaan dapat diinterpretasikan. 


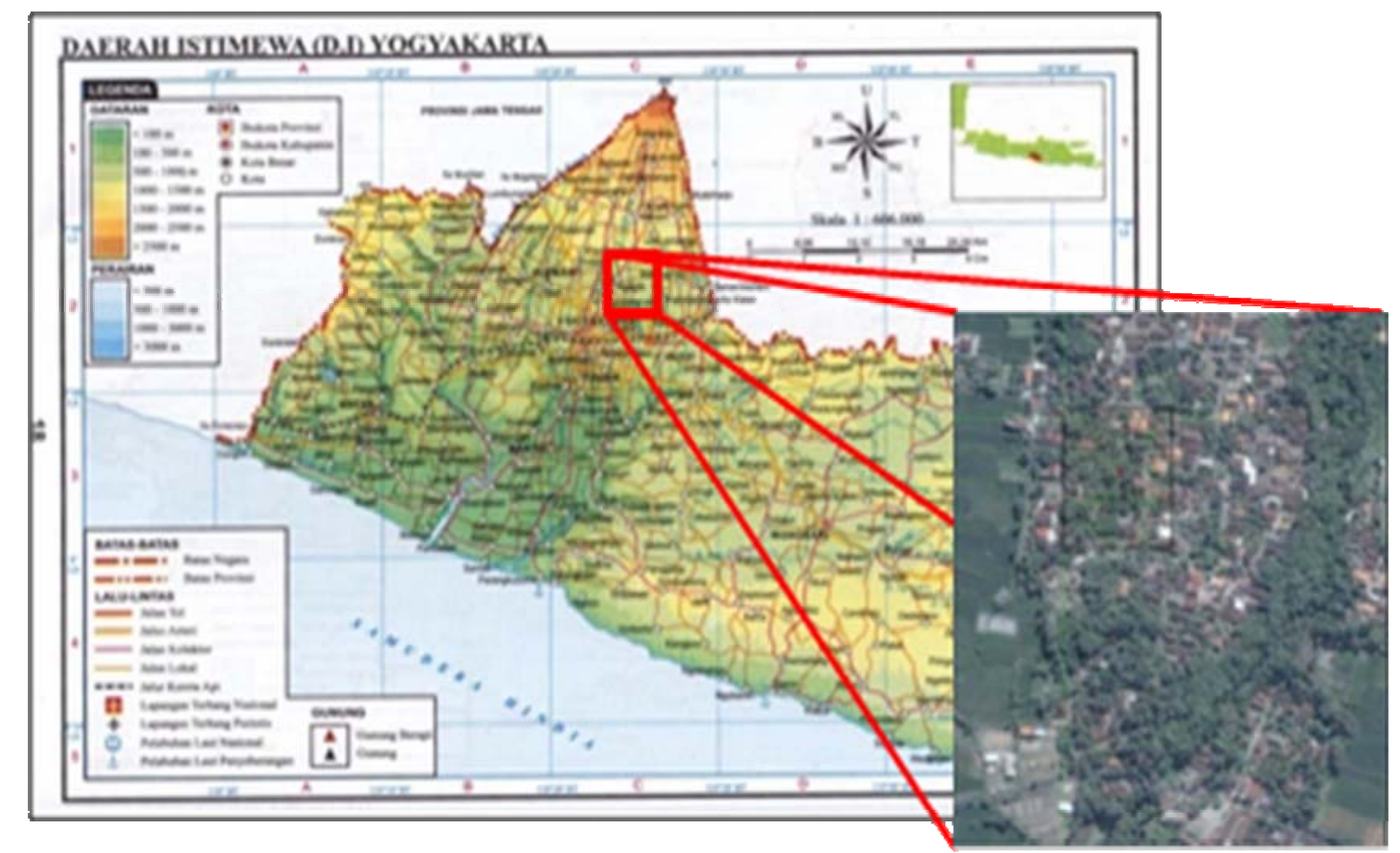

(Anonimous, 2009a)

(Anonimous, 2009b)

Gambar 1. Lokasi daerah penelitian, dusun Palgading, Sinduhardjo, Ngaglik, Sleman, Jogjakarta.

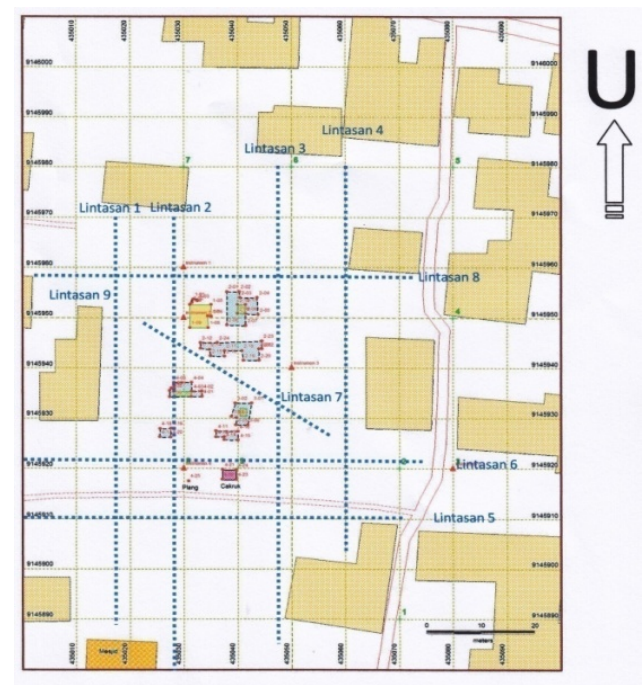

Gambar IV.5 Lintasan pengukuran daerah penelitian

Gambar 2. Lintasan pengukuran

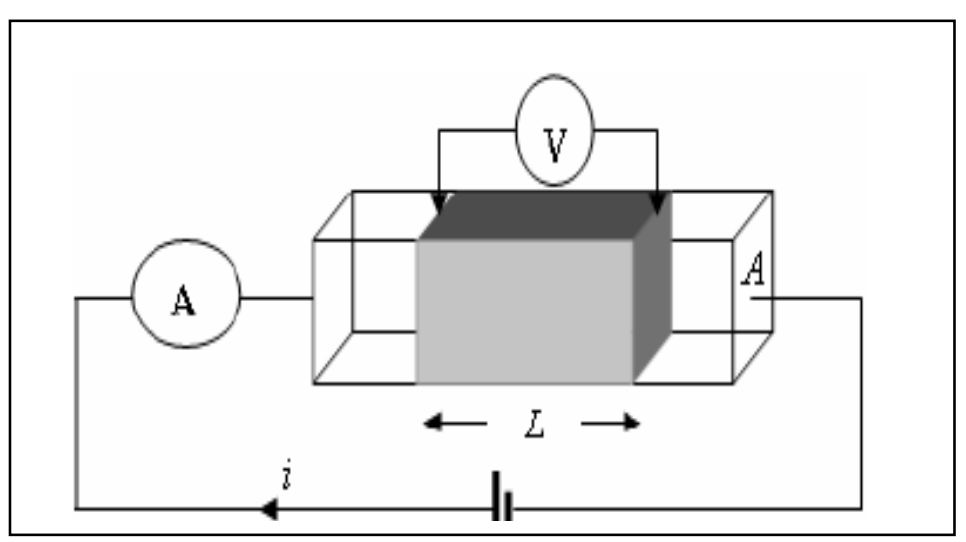

Gambar 3. Resistansi berbentuk balok dengan luasan sayatan A dan panjang L, beda potensial diukur pada kedua ujung kotak dengan arus I yang diketahui.

Teori dasar resistivitas adalah Hukum Ohm, dimana jika arus listrik dialirkan pada suatu resistor maka akan terjadi perubahan potensial pada ujung- ujung hambatan tersebut. Hubungannya adalah (Telford dkk,1990),

$R=\frac{\Delta V}{I}$

dengan adalah $R=$ Resistansi $(\Omega), I=$ Arus (Ampere), dan $\Delta V=$ Beda potensial (volt). Berdasarkan pengujian pengukuran suatu sampel batuan berbentuk balok dengan luas penampang A, panjang L dan resistansi R, (Gambar 3), maka didapatkan hubungan sebagai berikut (Telford dkk, 1990), 
$R=\rho \frac{L}{A}$

dengan $\rho$ adalah sebuah konstanta yang dikenal sebagai resistivitas suatu medium yang memiliki satuan $\Omega \mathrm{m}$ atau ohmmeter. Pada pengukuran langsung di lapangan, kondisi batuan yang diukur kondisinya berbeda, pada setiap perlapisannya memiliki nilai resistivitas yang berbeda-beda, sehingga dikenal adanya istilah resistivitas semu (apperent resistivity) yang dituliskan sebagai,

$$
\rho_{a}=K \frac{\Delta V}{I} \quad \text { dengan } \quad K=2 \pi\left[\frac{1}{r_{1}}-\frac{1}{r_{2}}-\frac{1}{r_{3}}+\frac{1}{r_{4}}\right]^{-1}
$$

$K$ dikenal dengan faktor geometri yang nilainya tergantung dari konfigurasi elektroda yang digunakan. Dalam survei resistivitas mapping dipenelitian ini digunakan konfigurasi lektroda Dipole Dipole, sehingga nilai $K$ diperoleh sebesar:

$K=\pi a n(n+1)(n+2)$

Dengan $a$ adalah spasi antar elektroda arus dan potensial, $n$ adalah posisi konfigurasi seperti yang dilukiskan pada Gambar 4.

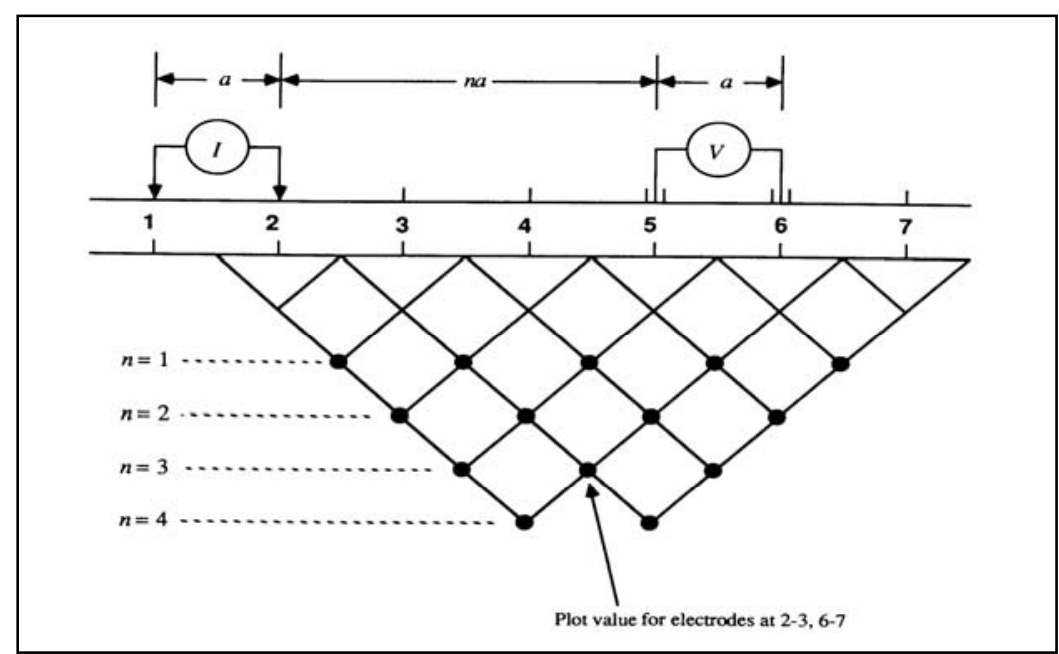

Gambar 4. Ilustrasi konfigurasi dipole-dipole.

\section{Metode Penelitian}

Peralatan utama yang dipakai dalam pengambilan data geolistrik adalah Resistivitymeter $\mathrm{McOhm}$ Mark-2 model-2115. Alat bantu yang diperlukan dalam pengambilan data lapangan antara lain:

1. Dua unit baterai luar (eksternal batteray) $12 \mathrm{~V}$

2. Satu rol pita meteran@100 meter

3. Empat rol kabel@100 meter

4. Empat unit elektroda logam

5. Empat unit palu 
6. Tiga unit HT untuk penghubung antara operator dengan kru pemindah elektroda

7. Satu tool set komplit

8. Satu unit multimeter

Dalam pengolahan data dipole dipole pada penelitian ini diasumsikan bahwa:

1. Batuan sekitar (penutup batuan candi) merupakan sedimen piroklastik, (endapan Gunung Merapi), dan

2. Batuan penyusun candi merupakan batuan beku andesit.

Hasil perhitungan data lapangan masih merupakan nilai resistivitas semu batuan. Data ini kemudian diolah dengan menggunakan program Res2dinv Ver.3.54, yang hasilnya berupa nilai resistivitas sebagai fungsi lateral dari tiap titik pengukuran. Hasil dari program Res2dinv Ver.3.54, dimasukkan ke dalam program Surfer 8 untuk dilihat nilai resistivitas pada kedalaman yang sama. Hasil yang diperoleh untuk memperkirakan keberadaan bagian dari situs candi.

Interpretasi dilakukan dengan menganalisa nilai resistivitas pada tiap-tiap lintasan untuk menentukan keberadan batuan beku(batuan andesit) yang merupakan batu penyusun candi yang ada di daerah penelitian. Seluruh hasil pengolahan data pada tiap lintasan pengukuran diinterpretasikan secara kualitatif kemudian dikorelasikan dengan kondisi geologi daerah penelitian.

\section{Hasil dan Pembahasan}

Parameter-parameter ukur yang diperoleh dari lapangan $(\Delta V, I, a$, dan posisi) diolah dengan menggunakan Res2dinv Ver.3.54. Hasilnya berupa tiga kontur isoresistivitas pada kedalaman semu (pseudodepth section), seperti yang ditampilkan pada gambar 5a sampai dengan gambar 5h. Penampang yang pertama (atas) menunjukkan kontur resistivitas semu, yaitu data yang diperoleh dari pengukuran di lapangan. Penampang vertikal kedua (tengah) menunjukkan kontur resistivitas semu dari hasil perhitungan respons model. Penampang yang terakhir (bawah) adalah kontur resistivitas pemodelan setelah melalui proses literasi. Untuk melihat resistivitas pada kedalaman yang sama, digunakan program Surfer 8 . Hasil olahan Surfer 8 dikelompokkan pada beberapa kedalaman yakni 0,5 m, $1 \mathrm{~m}, 2 \mathrm{~m}, 3 \mathrm{~m}, 4 \mathrm{~m}, 5 \mathrm{~m}$, dan $6 \mathrm{~m}$ yang disajikan pada gambar 6 , 7, dan 8 . Nilai resistivitas yang digunakan untuk menentukan batu andesit sekitar 750 Ohm-m sampai 5000 Ohm-m. Hal ini didasarkan pada range resistivitas batu andesit 1,7 x $10^{2} \mathrm{Ohm}-\mathrm{m}$ (dry) - 4,5 x $10^{4}$ Ohm-m(wet) (Telford dkk., 1990). Gambar 6 memberikan gambaran variasi nilai resistivitas terhadap kedalaman untuk lintasan 1. Pengukuran lintasan 1 ini membentang dari Utara ke Selatan 
dengan variasi nilai resistivitas 120 Ohm-m sampai 2500 Ohm-m. Nilai resistivitas yang memberikan dugaan batuan andesit berada sampai kedalaman sekitar 3,5 m dan 4,5 m yakni 750 Ohm-m sampai $2500 \mathrm{Ohm}-\mathrm{m}$. Gambar 7 memberikan gambaran variasi nilai resistivitas terhadap kedalaman untuk lintasan 2. Pengukuran lintasan 2 ini membentang dari Utara ke Selatan dengan variasi nilai resistivitas $120 \mathrm{Ohm}-\mathrm{m}$ sampai $5000 \mathrm{Ohm}-\mathrm{m}$. Nilai resistivitas yang memberikan dugaan batu andesit berada sampai kedalaman sekitar 3,5 m dan 4,5 m yakni 750 Ohm-m sampai 5000 Ohm-m, begitu pula pada Gambar 6 sampai Gambar 8.

a.

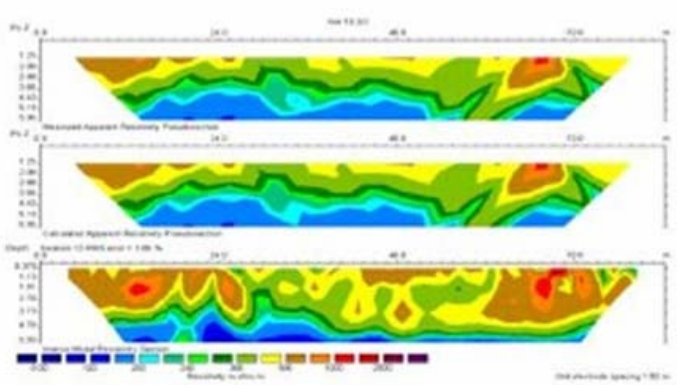

c.

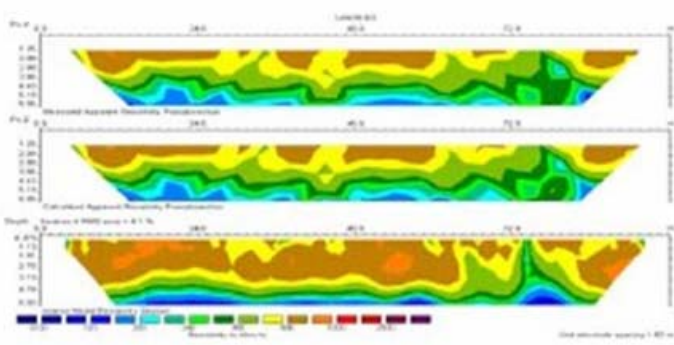

e.

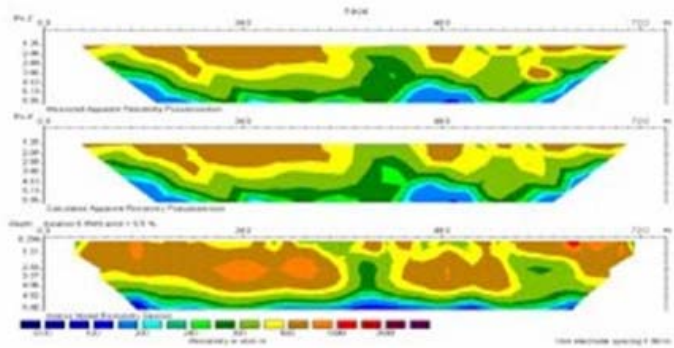

g.

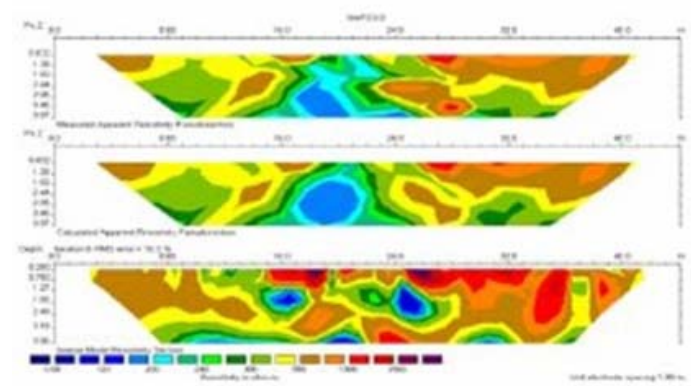

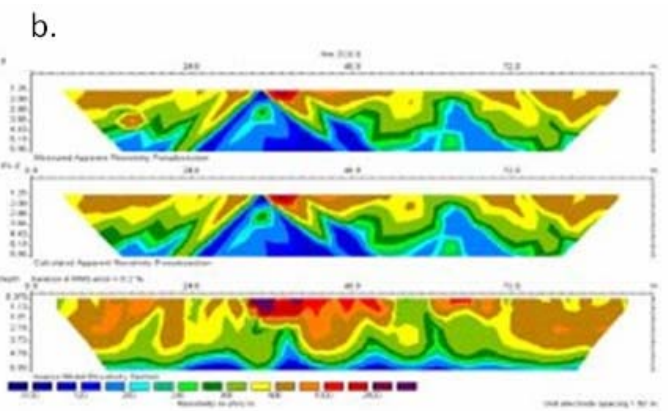

d.

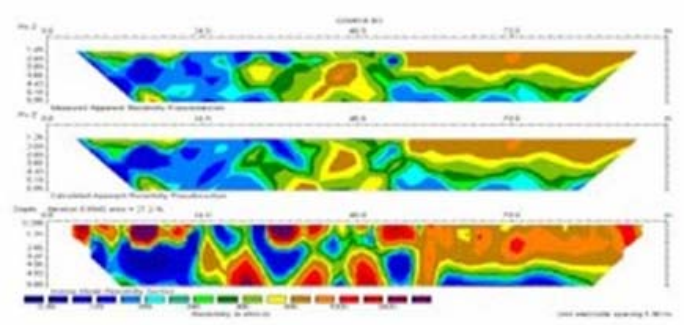

f.

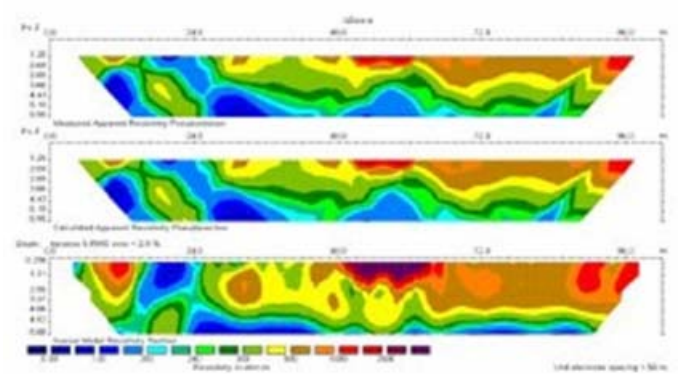

h.

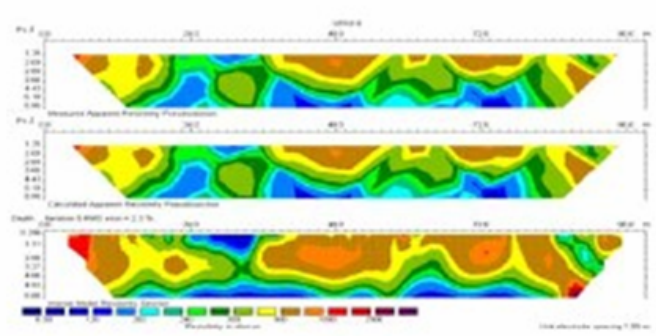

Gambar 5. Ploting data resistivitas semu hasil pengukuran (atas), respons model inversinya (tengah) dan model resistivitas hasil interpretasi untuk lintasan; $a$. Lintasan $1(\mathrm{~N} \rightarrow \mathrm{S})$;

$b$. Lintasan $2(\mathrm{~N} \rightarrow \mathrm{S}) ; c$. Lintasan $3(\mathrm{~N} \rightarrow \mathrm{S})$; $d$. Lintasan $4(\mathrm{~N} \rightarrow \mathrm{S}) ; e$. Lintasan $5(\mathrm{~W}->\mathrm{E})$; $f$. Lintasa $6(\mathrm{~W}->\mathrm{E}) ; g$. Lintasan $7(\mathrm{NW}->\mathrm{SE}) ; h$. Lintasan $8(\mathrm{~W}->\mathrm{E})$ 
Untuk melihat sebarannya diberikan Gambar 6, 7 dan 8 dengan pengelompokan kedalaman 0,5m, $1 \mathrm{~m}, 2 \mathrm{~m}, 3 \mathrm{~m}, 4 \mathrm{~m}, 5 \mathrm{~m}$, dan $6 \mathrm{~m}$. Sebaran nilai resistivitas pada gambar 6, 7 dan 8 adalah nilai-nilai yang diambil dari penampang bawah hasil olahan program software Res2dinv berupa resistivitas model sebenarnya untuk seluruh lintasan. Pada kedalaman $0,5 \mathrm{~m}$ dan $1 \mathrm{~m}$ nampak variasi nilai resistivitas yang berkisar antara $300 \Omega \mathrm{m}$ sampai $4800 \Omega \mathrm{m}$ dengan interval kontur $300 \Omega \mathrm{m}$. Pada kedalaman tersebut nampak bahwa daerah anomali terdapat pada beberapa lokasi yang ditunjukkan dengan meningkatnya nilai resistivitas batuan sampai dengan $4800 \Omega \mathrm{m}$.

Pada kedalaman $2 \mathrm{~m}$ variasi nilai resistivitas berkisar antara $300 \Omega \mathrm{m}$ sampai $3300 \Omega \mathrm{m}$. Pada kedalaman $3 \mathrm{~m}$ variasi nilai resistivitas berkisar antara $150 \Omega \mathrm{m}$ sampai $1500 \Omega \mathrm{m}$. Pada kedalaman 4 $\mathrm{m}$ variasi nilai resistivitas berkisar antara $150 \Omega \mathrm{m}$ sampai $2250 \Omega \mathrm{m}$. Pada kedalaman $5 \mathrm{~m}$ variasi nilai resistivitas berkisar antara $150 \Omega \mathrm{m}$ sampai $3300 \Omega \mathrm{m}$. Pada kedalaman $6 \mathrm{~m}$ variasi nilai resistivitas berkisar antara $300 \Omega \mathrm{m}$ sampai $4800 \Omega \mathrm{m}$.

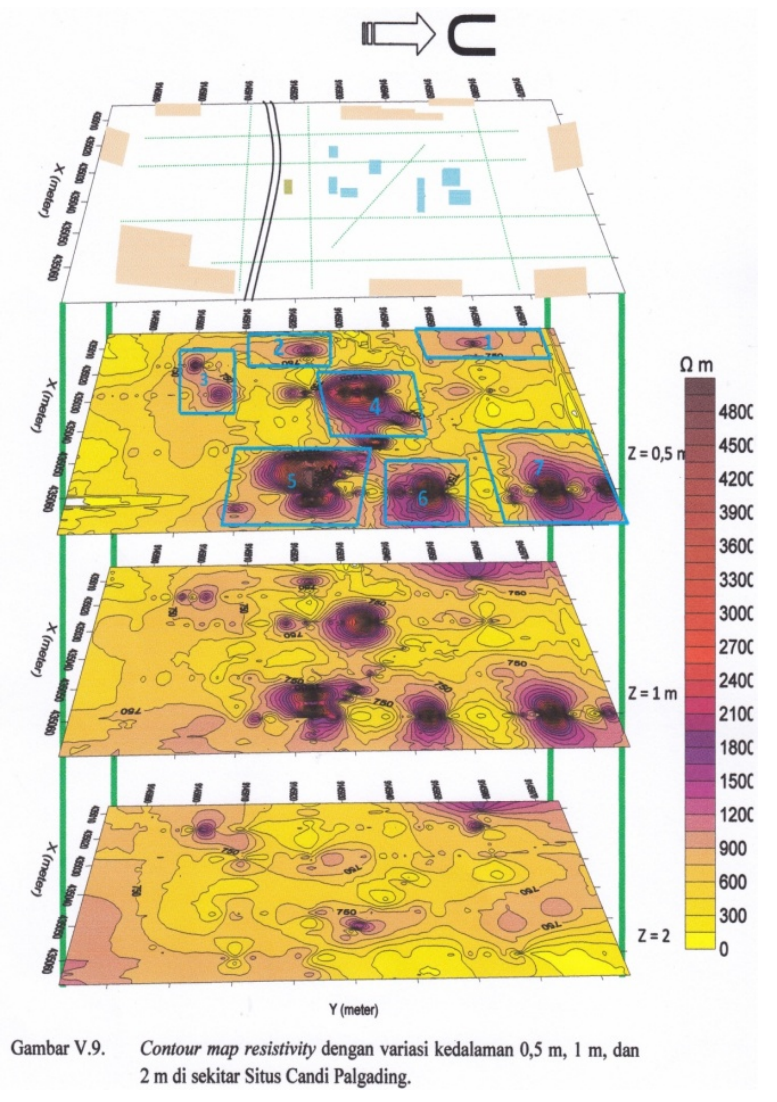

Gambar 6. Peta kontur resistivity dengan variasi kedalaman $0,5 \mathrm{~m}, 1 \mathrm{~m}$, dan $2 \mathrm{~m}$ di sekitar Situs Candi Palgading.

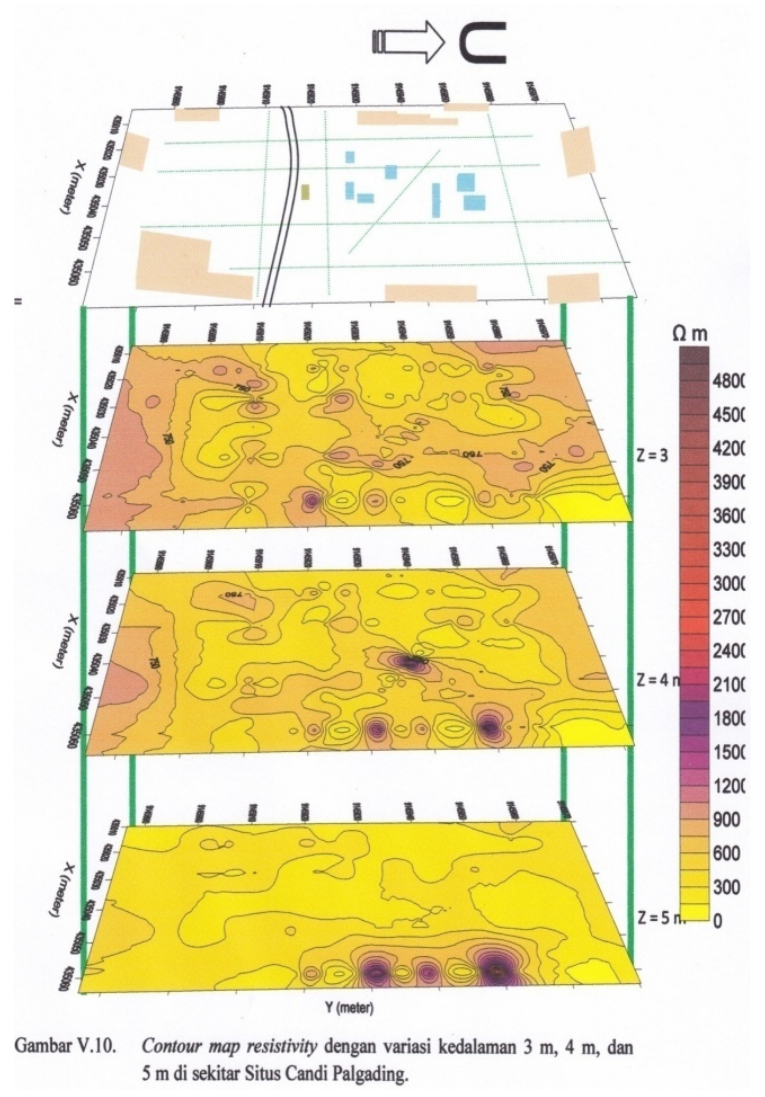

Gambar 7. Peta kontur resistivity dengan variasi kedalaman $3 \mathrm{~m}, 4 \mathrm{~m}$, dan $5 \mathrm{~m}$ di sekitar Situs Candi Palgading. 


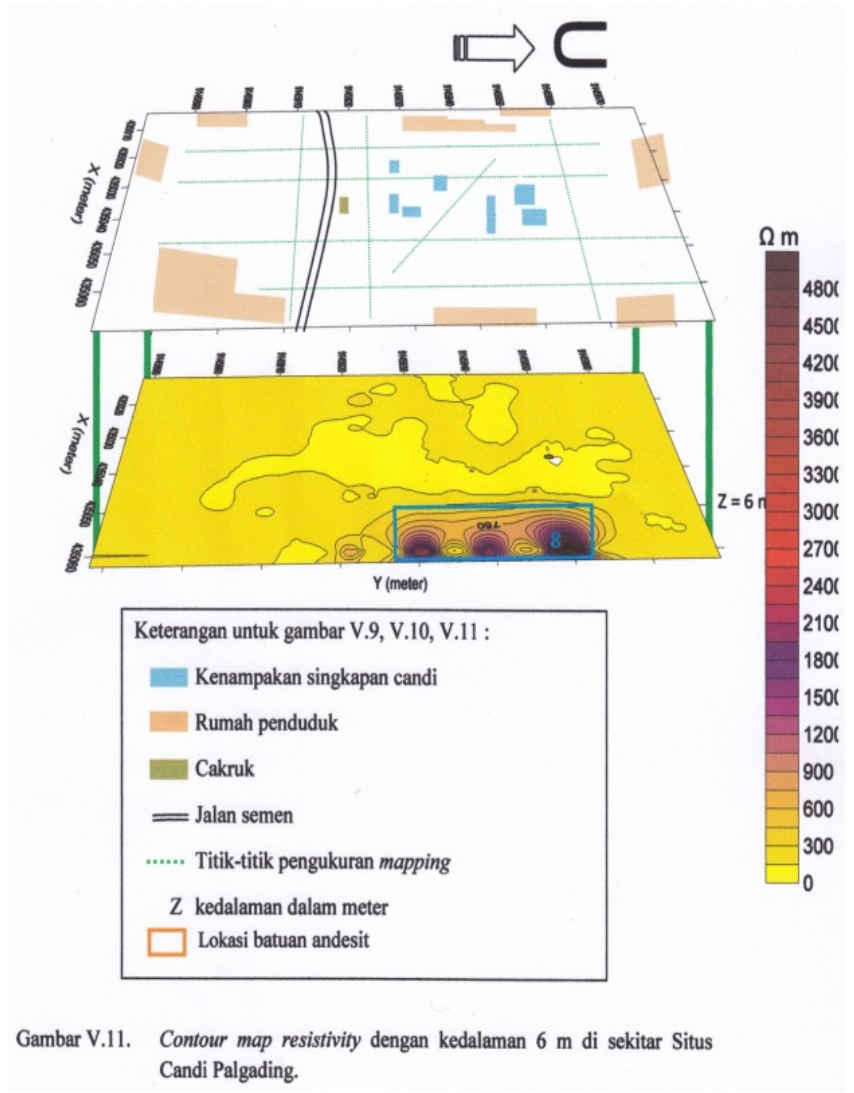

Gambar 8. Peta kontur resistivity dengan variasi kedalaman $6 \mathrm{~m}$ di sekitar Situs Candi Palgading.

Beberapa lokasi terlihat adanya kemenerusan anomali dengan bertambahnya kedalaman. Lokasi keberadaan anomali tersebut dapat dibagi dalam 8 lokasi yakni lokasi 1, lokasi 2, lokasi 3, lokasi 4, lokasi 5, lokasi 6, lokasi 7 dan lokasi 8. Dari peta kontur dengan kedalaman 0,5 m pada gambar 6, nampak adanya anomali resistivitas yang cukup tinggi. Anomali pada lokasi 1, 2, 3, mempunyai nilai resistivitas yang berkisar antara $750 \Omega \mathrm{m}$ sampai $1750 \Omega \mathrm{m}$ dan beberapa mencapai $4800 \Omega \mathrm{m}$ di lokasi 4, 5, 6, dan 7. Pada kedalaman $4 \mathrm{~m}$, anomali terlihat semakin berkurang dan di kedalaman $5 \mathrm{~m}$ dan $6 \mathrm{~m}$, anomali sudah tak terlihat lagi. Hal ini menunjukkan bahwa keberadaan anomali semakin berkurang dengan bertambahnya kedalaman. Berdasarkan informasi nilai resistivitas batuan, informasi geologi, dan survei lapangan, anomali pada lokasi tersebut diperkirakan sebagai batu beku andesit yang menjadi batuan penyusun candi yang masih terpendam. Pada lokasi 8 nampak adanya anomali resistivitas di kedalaman $6 \mathrm{~m}$. Jangkauan resistivitas pada lokasi 8 berkisar antara $750 \Omega \mathrm{m}$ sampai $4800 \Omega \mathrm{m}$. Nilai resistivitas semakin berkurang dengan berkurangnya kedalaman. Di kedalaman $3 \mathrm{~m}$ anomali masih terlihat dan di kedalaman $2 \mathrm{~m}$ sampai 0,5 m, anomali sudah tak terlihat lagi. Berdasarkan informasi nilai resistivitas batuan, informasi geologi, dan survei lapangan, anomali pada lokasi 8 ini diperkirakan sebagai batuan beku (batuan andesit) lain yang berasal dari Gunung api namun bukan sebagi batuan penyusun candi. 


\section{Kesimpulan}

a. Dugaan penyebaran batuan penyusun candi di Situs Candi Palgading terdapat tujuh lokasi dengan lokasi 4 merupakan lokasi batuan candi yang tersingkap sedang lokasi lainnya masih terpendam.

b. Dugaan kedalaman batuan penyusun candi terpendam di Situs Candi Palgading sekitar 4,5 meter.

c. Saran dari penelitian ini adalah melanjutkan penggalian dengan lokasi-lokasi dugaan adanya batu candi tersebut.

\section{Daftar Pustaka}

Asmanto, H. (2002). Penyelidikan Situs Purbakala Candi Kadisuko di Kalasan-DIY dengan Menggunakan Metode Resistivitas, Skripsi S-1, FMIPA, UGM, Yogyakarta.

Anonimous. (2009a). Atlas Indonesia dan Sekitarnya, CV. Buana Raya, Jakarta.

Anonimous. (2009b). Google Earth Yogyakarta Satelit Map.

Faridl, A. (1997). Penyelidikan Keberadaan Batuan Situs Purbakala Candi Kedulan dengan Metode Resistivitas, Skripsi S-1, Geofisika UGM, Yogyakarta.

Sismanto, dan Zaman, M.T. (2005). Penyelidikan Penyebaran Batuan Situs Purbakala Candi Morangan dengan Metode Resistivitas, Prosiding Seminar Nasional FMIPA UGM, Yogyakarta.

Telford, W.M., Geldart, L.P., and Sheriff, R.E. (1990). Applied Geophysics. Second Edition, Cambridge University Press, London. 